\title{
Otolith dimensions (length, width), otolith weight and fish length of Sardinella sindensis (Day, 1878), as index for environmental studies, Persian Gulf, Iran
}

\author{
Mohsen Dehghani ${ }^{1,3^{*}}$, Ehsan Kamrani ${ }^{1}$, Ali Salarpouri ${ }^{2}$ and Sana Sharifian ${ }^{1,3}$
}

\begin{abstract}
Background: Sardines are the most important commercial fishes for Iran. However, information about biology and ecology of sind sardine in Persian Gulf and Oman Sea is scarce.

Methods: In this study, relationship between fish length and otolith length, -width and -weight of Sardinella sindensis from Bandar Lengeh and Qeshm Island, Persian Gulf were analyzed. In total, 128 and 120 fishes collected from Commercial catches during March 2011- February 2012 in the Bandar Lengeh and Qeshm Island respectively.

Results: There were no significant differences between left and right otolith ( $t$-test, $P>0.05$ ) or between males and females otoliths (ANCOVA, $P>0.05$ ). For these reasons, only right otoliths were used for next analysis and data of both sexes were pooled. Relationships between fish length and otolith length, width and weight were described by linear regression models and high correlation was shown for all relationships. The highest correlation was between fish length and otolith length (Bandar Lengeh, $R^{2}=0.8722$; Qeshm Island, $R^{2}=0.8661$ ) and relationship between fish length and otolith width showed less correlation than other relationships (Bandar Lengeh, $R^{2}=0.7355$; Qeshm Island, $\left.R^{2}=0.7275\right)$.
\end{abstract}

Conclusions: The result from this study shows that fish length and otolith growth have a positive relationship, so can be a useful tool to evaluate the growth of fish and fish stocks and finally fisheries management.

Keywords: Fish length, Otolith, Sardinella sindensis, Persian Gulf

\section{Background}

The inner ears of all teleost fishes contain three calcified structures, which acts as balance and hearing organs (Popper et al. 2005). Otoliths serve as a permanent record of the life history of an individual fish (ICES 2004), and they hold a wealth of information on daily age, size, growth and ontogeny of fishes (Gerard \& Malca, 2011). The otoliths continue to grow throughout their life and do not resorb in time of stress (Yaremko, 1996; Mendoza, 2006). Thus, they are one of the most reliable tools for identification of growth rates, structure of age in a certain

\footnotetext{
*Correspondence: mohsen.dehghani64@gmail.com

'Department of Marine Biology, Faculty of Basic Sciences, University of Hormozgan, P.O.Box: 3995, Bandar Abbas, Iran

${ }^{3}$ Young Researcher and Elite Clube, Islamic Azad University, Bandar abbas Branch, P.O.Bbox: 79159-1311, Bandar Abbas, Iran

Full list of author information is available at the end of the article
}

population and for fisheries management, furthermore the analysis of microstructure otolith have greatly developed for stock identification, feeding ecology of predators, and the determination of migration direction in fishes species (Campana \& Thorrold, 2001; Mendoza 2006, McFarlane et al. 2010). The application of otolith only is not restricted to ichthyology, but also extended widely for some aspects of palaeontology, stratigraphy, archaeology and zoogeography (Tuset et al. 2008). The size and shape of otoliths are variable according to species and size of fish (Eroglu \& Sen, 2009). The relationship between fish length and otolith dimensions, can be useful to estimate the size and age of prey collected from stomach and feeding habits of fishes (Hunt, 1992; Granadeiro \& Silva, 2000; Khodadai \& Emadi, 2004, Pombo et al. 2005, Rizkalla \& Bakhoum, 2009; Javor et al. 2011). 
Sardines are small pelagic fishes that live in coastal waters of many sea and ocean. They feed on planktons and are eaten by other fishes, so they are important in marine food web (Emmett et al. 2005; Salarpouri et al. 2009). In addition, sardines are consumed as fresh meal for humans and as commercial powder (Bennet et al. 1992; Hill et al. 2005; FAO, 2011). Many studies for sardine genus have been performed on the otolith structures, such as growth and mortality estimation, identification of fishes, determine the fish stock and trace migration pathway of fish (Nair, 1949; Krzeptowski, 1983; Cergole \& Valentini 1994; Butler et al. 1996; Watanabe \& Nakamura, 1998; Gaughan \& Mitchell, 2000, Silva et al. 2008; Mehanna \& Salem 2011; Ward et al. 2012; Dehghani et al. 2015). According to FAO (2011), Sardinella sindensis is the most important commercial fish for Iran and Pakistan. However, a few studies have been performed on the structure of otoliths in S.sindensis from Iran. The age and growth of S.sindensis was studied using annual rings of otoliths from Persian Gulf and Oman, Iran by Dehghani et al (2015). Otoliths tend to grow linearly in length and width with increasing fish size, and to grow linearly in thickness and weight with increasing fish age (Donkers, 2004). For most species, the relationship between otolith length and fish length can be described by a simple linear regression (Harvey et al. 2000).
The aim of this study was to gain understanding of the relationships between fish length and otolith dimensions of S.sindensis, through regression analysis.

\section{Methods}

Fishes were selected, randomly, from commercial catches using purse seine nets. A total of 120 fishes were collected from coastal waters of Bandar Lengeh (26 $55^{\prime}$

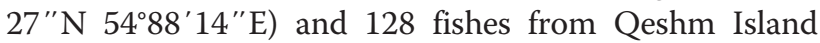
$\left(26^{\circ} 41^{\prime} 43^{\prime \prime} \mathrm{N} 55^{\circ} 37^{\prime} 06^{\prime \prime} \mathrm{E}\right)$ in North of Persian Gulf (Iran) during March 2011 to February 2012 (Fig. 1). Fishes were transported to the laboratory of Persian Gulf and Oman Sea Ecological Research Institute, Bandar Abbas.

First, total fish length was measured to the nearest $0.1 \mathrm{~mm}$, and then sex determination was done under stereomicroscope. Chi-square test was performed for sex differences. Otoliths were extracted from heads of samples, cleaned and dried. Otolith weight was measured by using digital balance to the nearest $0.0001 \mathrm{~g}$. For measuring the otolith size, images were taken under a stereo microscope linked to a video camera (Motic Image Plus 2 ), and otolith length and -width were measured using imaging software (Motic 2) to the nearest $0.01 \mu \mathrm{m}$. Otolith length is the distance from the midpoint of the rostrum at point A through the primordium to the posterior edge at

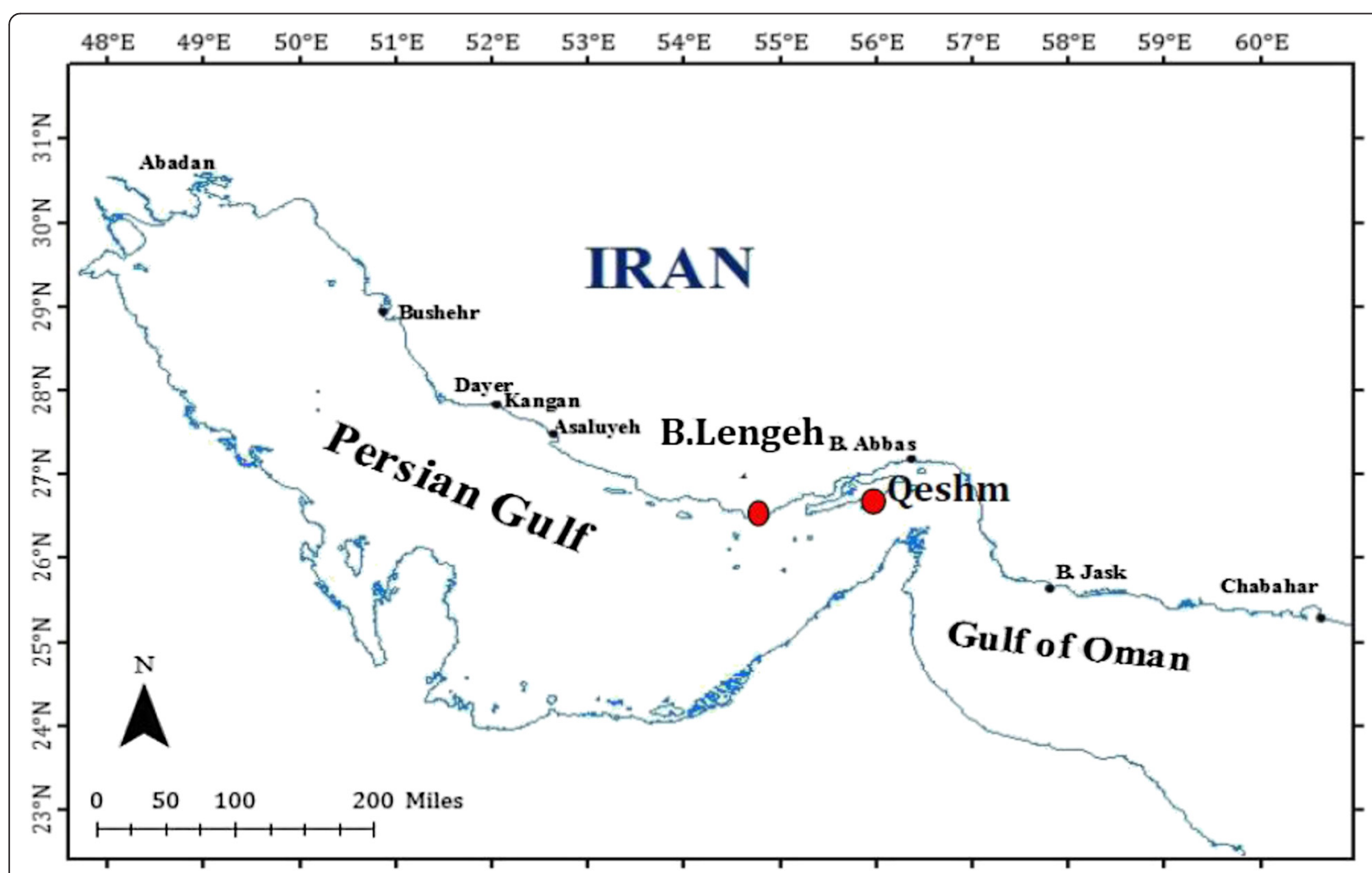

Fig. 1 Sampling areas of Sind sardine, Sardinella sindensis, Bandar Lengeh and Qeshm Island, Persian Gulf, Iran 


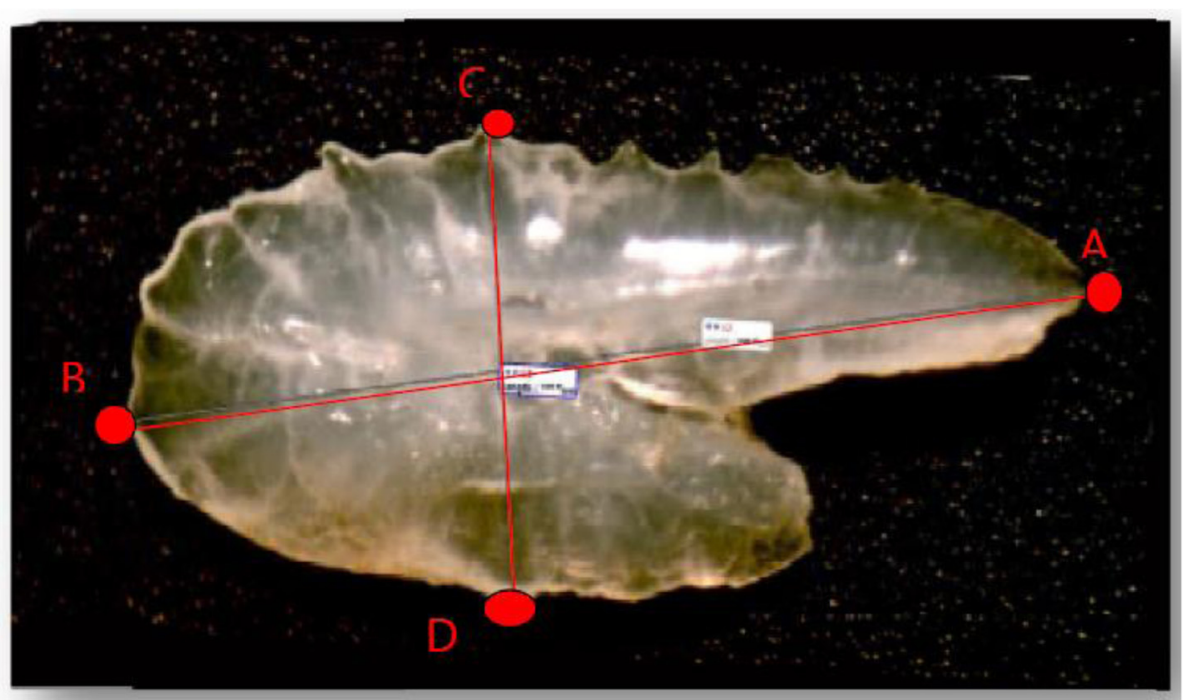

Fig. 2 Otolith of S. sindensis, distance between point A and B indicating otolith length and distance between point C and D indicating otolith width

point $\mathrm{B}$. Width is the distance perpendicular to the length passing through the primordium (Fig. 2) (Javor et al. 2011). Differences between left and right otolith were tested by paired $t$-test and between males and females by using ANCOVA (Matic-Skoko et al. 2011). ANOVA was used to test for significant differences in area. Relationships between total fish length and otolith length and -width described by linear equation as $\mathrm{TL}=\mathrm{a}(\mathrm{L}) \mathrm{b}$, where $\mathrm{TL}$ is total fish length, $\mathrm{L}$ is otolith length or otolith width, and $\mathrm{a}, \mathrm{b}$ are constant coefficients. For express relationship between total length fish and otolith weight was used a linear equation like above equation that described as $\mathrm{TL}=$ a $(\mathrm{OW}) \mathrm{b}$, where OW is otolith weight. Regression method was analyzed by using Excel software (version 2007) for determining the relationships between fish length and otolith length,-width and -weight.

\section{Results}

In total, 128 fishes from Qeshm Island and 120 fishes from Bandar Lengeh collected (Fig. 3). Chi-square test was performed assuming equal sex ratio and results with a degree of freedom, did not show significant differences between the sexes $\left(X^{2}=1.2, d f=1, p>0.05\right)$ and $\left(X^{2}=\right.$ $1.125, d f=1, p>0.05)$ for Bandar Lengeh and Qeshm, respectively.

Minimum-maximum and mean fish lengths for Bandar Lengeh were 8.1-18.3 and $12.7 \mathrm{~cm}$ respectively and those for Qeshm were 7.9-18.6 and $12.9 \mathrm{~cm}$, respectively. All measurement of left and right otoliths were tested and no significant differences were observed between left and right otolith $(t$-test, $P>0.05)$ and between otoliths of female and males (ANCOVA, $P>0.05$ ), therefore, only right otolith used for next analysis and data of both the sexes were pooled. Otolith length, -width and -weight measurements in addition fish length and weight are recorded in Table 1.

Relationships between fish length and otolith length, -weight and -width were described by regression model and linear equation. The equation for otolith length and fish length was $\left(O L=171.51 \mathrm{TL}+257.63 ; R^{2}=0.8661\right)$ for Qeshm Island and $\left(O L=165.06 \mathrm{TL}+401.64 ; R^{2}=\right.$ 0.8661) for Bandar Lengeh. Regression models and linear equations of all relationships are shown in Figs. 4, 5 and

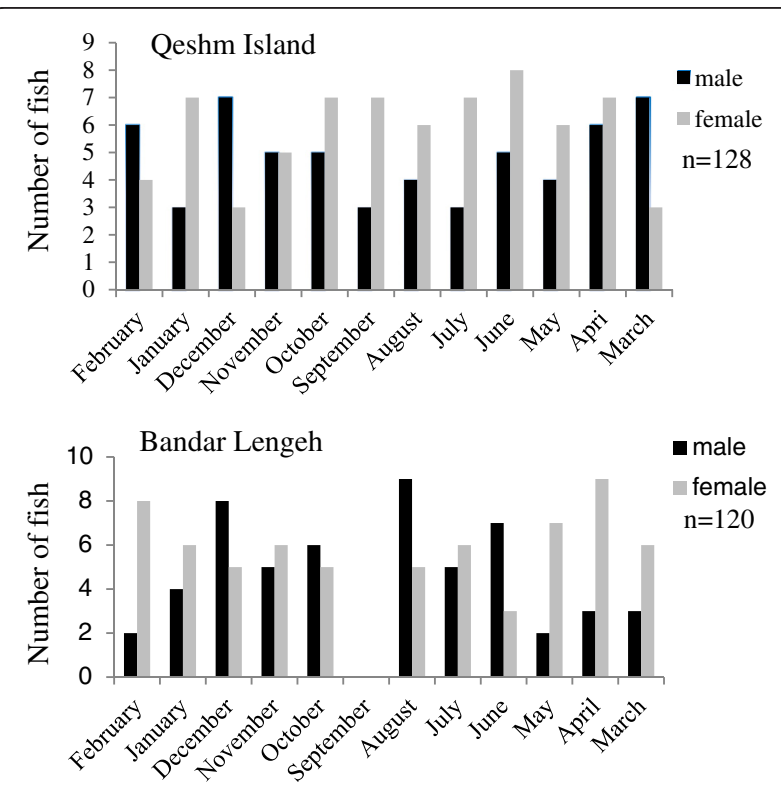

Fig. 3 Number of S.sardinella collected from Bandar Lengeh and Qeshm Island (Persian Gulf) during March 2011 to February 2012 
Table 1 Maximum, minimum, mean and standard deviation (SD) of fish length and otolith length, -width and -weight of S.sindensis from Bandar Lengeh and Qeshm Island (Persian Gulf)

\begin{tabular}{|c|c|c|c|c|c|c|}
\hline Area & & Number & Minimum & Maximum & Mean & SD \\
\hline \multirow[t]{4}{*}{ Bandar Lengeh } & Total fish length $(\mathrm{cm})$ & 120 & 7.9 & 18.6 & 13 & 2.7 \\
\hline & Otolith length $(\mu \mathrm{m})$ & 118 & 1620.06 & 3389.02 & 2503.06 & 511.37 \\
\hline & Otolith width $(\mu \mathrm{m})$ & 118 & 954.24 & 1504.88 & 1250.78 & 153.52 \\
\hline & Otolith weight (g) & 118 & 0.0004 & 0.0026 & 0.0013 & 0.00061 \\
\hline \multirow[t]{4}{*}{ Qeshm Island } & Total fish length $(\mathrm{cm})$ & 128 & 8.1 & 18.3 & 12.9 & 2.7 \\
\hline & Otolith length $(\mu \mathrm{m})$ & 124 & 1610.28 & 3556.98 & 2533.7 & 476.5 \\
\hline & Otolith width $(\mu \mathrm{m})$ & 124 & 973.43 & 1533.05 & 1237.7 & 132.8 \\
\hline & Otolith weight (g) & 124 & 0.0003 & 0.0027 & 0.0014 & 0.00064 \\
\hline
\end{tabular}

6. There were no significant differences in these analyses for two areas (ANOVA, $P>0.05$ ).

\section{Discussion}

In this study, relationship between fish length and otolith length, -width and -weight was analyzed by linear model. Otolith dimensions and weight was linearly correlated to total fish length. Relationships between fish length and otolith length for each area showed highest positive correlation, that is similar to results of Sardina Pilchardus from Adriatic Sea, Crotia (Zorica et al. 2010), those of Sardinops sagax from North America (Javor 2013), S.sagax

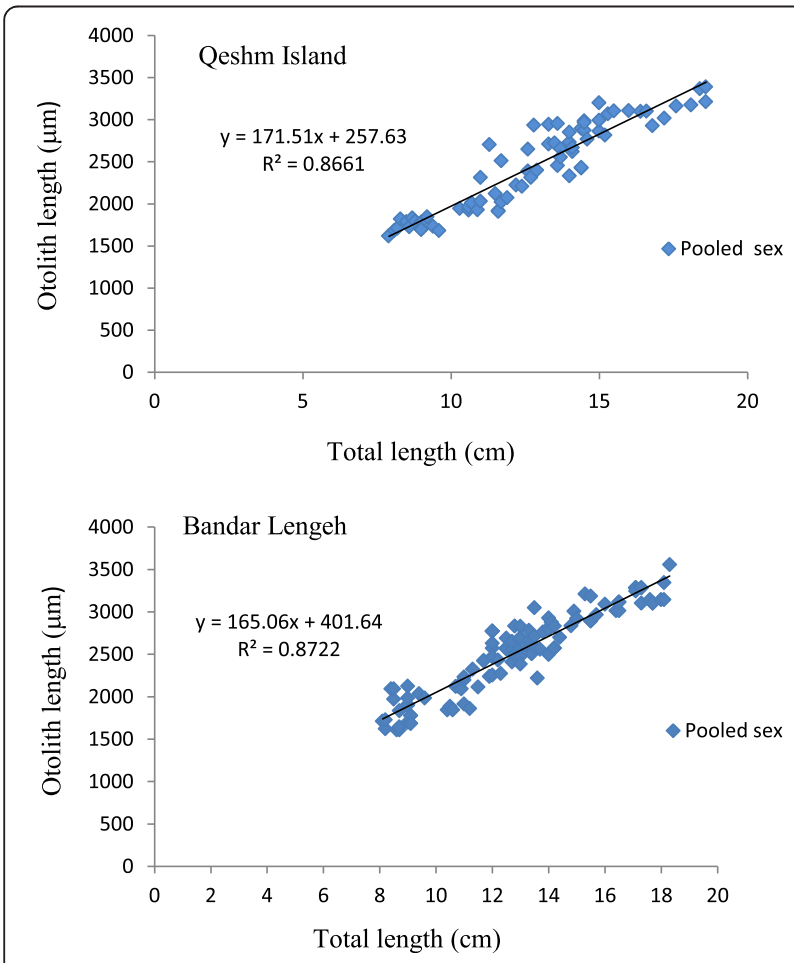

Fig. 4 Relationship between total fish length and otolith length of S.sindensis from Bandar Lengeh and Qeshm Island (Persian Gulf) from Australia (Gaughan et al. 2008) and other fish species (Hunt, 1992; Megalofoou 2006; Ilkyaz et al. 2011).

In current study, results of testing the difference between right and left otoliths showed no significant difference, and no significant difference between males and females otoliths. In addition, this test was similar for the two sampling regions. These results agree with results of other studies (Jawad et al. 2011), but differ from studies done on Sardina Pilchardus from Adriatic Sea, Crotia (Zorica et al. 2010), Sardinops sagax from west coast of North America (Javor et al. 2011) and were different from results of other fishes (Clark, 1992; Sen et al. 2001; Aydin et al. 2004). It can be stated that fishes from different regions have different allometric growth of the otolith (Butler et al. 1996), the reason for these
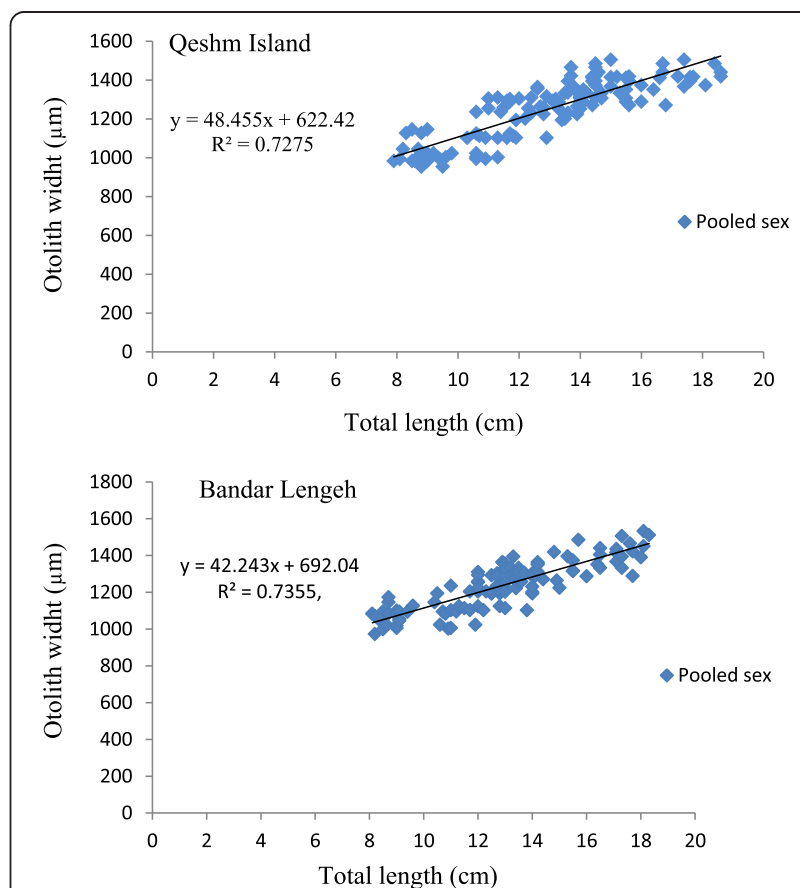

Fig. 5 Relationship between total fish length and otolith width of S.sindensis from Bandar Lengeh and Qeshm Island (Persian Gulf) 


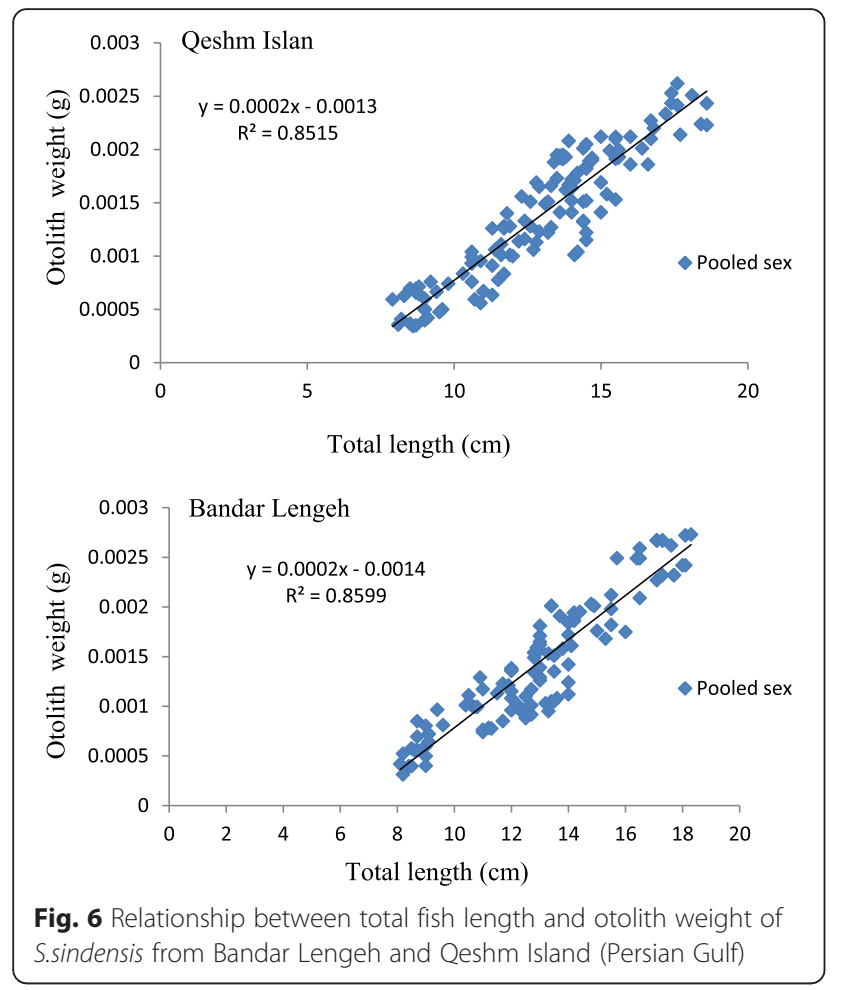

difference in relationship in different studies, could be the differences in fish species, habitat, food availability and physiochemical factors of waters of environment that lives there (Aydin et al. 2004; Javor et al. 2011). There are a number of things that could conceivably produce a shift in the otolith size-body size relationship in the commercial catch, including large changes in age or sex composition, or changes in regulations, gear, or fishing strategies, even different methods used for analysis (Clark, 1992; Ma et al. 2010).

The results of this study suggested that otolith dimensions increases as fish length increases and therefore, otolith growth can be correlated with fish growth. In addition, the results showed that the otolith length had more correlation to the fish length than otolith weight and -width, respectively, it is similar to study done on S.lemuru from Australia (Gaughan and Mitchell, 2000) and other fishes (Metin \& Ilkyaz 2006; Matic-Skoko et al. 2011).

Lombarte and Lleonart (1993) suggested that otolith development occurs under dual regulation: genetic conditions regulate the form of the otolith, while environmental conditions, mainly temperature in carbonate-saturated waters, regulate the quantity of material deposited during the formation of the otolith. Butler et al (1996) reported that it was not possible to use otolith weight with other data to estimate age of Pacific sardine. The regression method is very appealing in its simplicity but has two drawbacks. It will often be necessary to transform predictors and (or) the predict to obtain linear relationships, and even then, this is likely to achieve only approximate linearity. The second, and more serious, drawback is that this method produces asymptotically biased estimates of proportions at age (Francis \& Campana, 2004), however, linear regressions between age-otolith size, unlike annulus counting methods, to estimate the age structure of the Sardines population need lesser time and cost (Ward et al. 2005; Ward et al. 2012).

\section{Conclusions}

morphometric relationships are useful tools for testing feeding and for research on fish fossils, especially for determining the size of fish that it is important factor for fish stock monitoring and management. However, for better understanding of otolith growth, it can be recommended for future studies to use the relationships between otolith weight and age, and to measure other otolith factors such as area, perimeter, thickness, circularity, and rectangularity.

\section{Abbreviations}

Ancova, analysis of covariance; Anova, analysis of variance; Df, degree of freedom; OL, otolith length; OW, otolith weight; $P$, probability; $R^{2}$, coefficient of determination; $\mathrm{Sd}$, standard deviation; $\mathrm{TL}$, total length

\section{Acknowledgements \\ We appreciate and would like to thank the director and staff of the Persian Gulf and Oman Sea Ecological Research Institute for contributions in laboratory facilities.}

\section{Funding}

This work was carried out without any the funding and supporting from academic and research centers.

\section{Availability of data and materials}

The data will not be shared with a reason, in this section.

\section{Authors' contributions}

MD carried out biometric and otoliths analysis of fishes, statistical analysis, and writing of paper; EK was superviser and the overall structure of paper was confirmed by him; AS assisted in sampling of fishes, and extracting of otoliths; SS cooperated in statistics analysis and writing of paper. All authors have read and approved the final manuscript.

\section{Competing interests}

The authors declare that they have no competing interests.

\section{Author details}

${ }^{1}$ Department of Marine Biology, Faculty of Basic Sciences, University of Hormozgan, P.O.Box: 3995, Bandar Abbas, Iran. ${ }^{2}$ Department of Stock assessment, Persian Gulf and Oman Sea Ecological Research Institute, P.O.Box: 1597, Bandar Abbas, Iran. ${ }^{3}$ Young Researcher and Elite Clube, Islamic Azad University, Bandar abbas Branch, P.O.Bbox: 79159-1311, Bandar Abbas, Iran.

Received: 16 May 2016 Accepted: 3 June 2016

Published online: 08 July 2016

\section{References}

Aydin R, Calta M, Sen D, Coban MZ. Relationships between fish lengths and otolith length in the population of Chondrostoma regium (Heckel, 1843) Inhabiting Keban Dam Lake. Pak J Biol Sci. 2004;7:1550-3. 
Bennet PS, Nair PNR, Luther J, Annigeri GG, Rangans SS, Kurup KN. Resource characteristics and stock assessment of lesser sardines in the Indian waters. Indian J Fisheries. 1992;39:136-51.

Butler JL, Granados-G ML, Barnes JT, Yaremko M, Macewicz BJ. Age composition, growth and maturation of the Pacific Sardine, Sardinops sagax, during 1994. Calif Cooperative Oceanic Fisheries Invest Rep. 1996;37:152-9.

Campana SE, Thorrold SR. Otoliths, increments, and elements: keys to a comprehensive understanding of fish populations? Can J Fish Aquat Sci. 2001;58:30-8.

Clark WG. Estimation of Halibut body size from otolith size. Int Pac Halibut Commission Sci Rep No. 1992;75:1-31.

Cergole MC, Valentini H. Growth and mortallty estlmates of Sardinella brasiliensis in the Southeastern brazillian bight. Bol Inst Oceanografico Sao Paulo. 1994;42:113-27.

Dehghani M, Kamrani E, Salarpouri A, Kamali E. Age and growth of Sind sardine (Sardinella sindensis) using otolith from Qeshm Island (Persian Gulf). Iran J Fisheries Sci. 2015;14:217-31.

Donkers PD. Age, Growth and Maturity of European Carp (Cyprinus carpio) in Lakes Sorell and Crescent. Technical Report No.4 Inland Fisheries Service, Hobart. 2004. p. 18

Emmett RL, Brodeur RD, Miller TW, Pool SS, Krutzikowsky GYK, Bentley PJ, et al. Pacific sardine (Sardinops sagax) abundance, distribution, and ecological relationships in the Pacific Northwest. Calif Cooperative Oceanic Fisheries Invest Rep. 2005;46:122-43.

Eroglu M, Sen D. Otolith size-total length relationship in Spiny eel, Mastacembelus mastacembelus (Banks\& Solander, 1794) inhibiting in Karakaya Dam lake (Malatya, Turkey). J Fisheries Scicom. 2009;3:342-51.

FAO. Report of the FAO workshop on the status of shared fisheries resources in the Northern Arabian Sea - Iran (Islamic Republic of), Oman and Pakistan which was held in Muscat, Oman, from 13 to 15 December 2010. FAO Fisheries and Aquaculture Report 971. Karachi, FAO. 2011. p. 58. http:// fishbase.org/listbyletter/FBReferencesF.htm.

Francis RICC, Campana SE. Inferring age from otolith measurements: a review and a new approach. Can J Fish Aquat Sci. 2004:61:1269-84.

Gaughan D, Mitchell RWD. The biology and stock assessment of the tropical sardine, Sardinella lemuru, off the mid-west coast of Western Australia Fish. Western Australia: Final report to Fisheries Research and Development Corporation on Project No. 95/037: Fisheries Research Report No. 119, Department of Fisheries; 2000. p. 136.

Gaughan D, Craine M, Stephenson P, Leary T, Lewis P. Re growth of pilchard (Sardinops sagax) stocks off southern WA following the mass mortality event of 1998/99. Final report to Fisheries Research and Development Corporation on Project No. 2000/135. Western Australia: Fisheries Research Report No. 176, Department of Fisheries; 2008. p. 82

Gerard TL, Malca E. Silver nitrate staining improves visual analysis of daily otolith increments. J Am Sci. 2011;7:120-4

Granadeiro JP, Silva MA. The use of otoliths and vertebrae in the identification and size-estimation of fish in predator-prey studies. Cybium. 2000;24:383-93.

Harvey JT, Loughlin TR, Perez MA, Oxman DS. Relationship between fish size and otolith length for 63 species of fishes from the eastern North Pacific Ocean. NOAA Tech Rep NMFS. 2000;150:35.

Hill KT, Lo NCH, Macewicz BJ, Felix-Uraga R. Assessment of the Pacific sardine (Sardinops sagax caerulea) population for U.S. management in 2006. Pacific Fishery Management Council, Agenda Item D.1.a, Supplemental Attachment. 2005. p. 1-141.

Hunt JJ. Morphological characteristics of otoliths for selected fish in the Northwest Atlantic. J Northwest Atl Fisheries Sci. 1992;13:63-75.

ICES. Recruitment studies: Manual on precision and accuracy of tools. By Belchier M., Clemmesen C., Cortes D., Doan T., Folkvord A., Garcia A., Geffen A., Hoie H., Johannessen A., Moksness E., de Pontual Ramirez T., Schnack D., Sveinsbo B. ICES Tech Mar Environ Sci. 2004;33:35.

Ilkyaz AT, Metin G, Kinacigil HT. The use of otolith length and weight measurements in age estimations of three Gobiidae species (Deltentosteus quadrimaculatus, Gobius niger, and Lesueurigobius friesii). Turk J Zool. 2011;35:819-27.

Javor B. Do shifts in otolith morphology of young Pacific Sardine (Sardinops Sagax) reflect changing recruitment contributions from Northern and Southern stock? Calif Cooperative Oceanic Fisheries Invest Rep. 2013;54:12.

Javor B, Lo N, Vetter R. Otolith morphometrics and population structure of Pacific sardine (Sardinops sagax) along the west coast of North America. Fish Bull. 2011;109:402-15.

Jawad LA, Ambuali A, Al-Mamry JM, Al-Busaidi HK. Relationships between fish length and otolith length, width and weight of the Indian Mackerel Rastrelliger kanagurta (Cuvier, 1817) collected from the Sea of Oman. Ribarstvo. 2011;69:51-61.
Khodadai M, Emadi $\mathrm{H}$. Aging of Epinephelus coioides by using of section of sagita in province waters (Persian Gulf, Khouzestan). Pajouhesh Sazandegi. 2004;63:2-11.

Krzeptowski M. Biological characteristics of the sardine (Sardina pilchardus Walb) off west Sahara. Acta Ichthyologica Piscatoria. 1983;8:13-38.

Lombarte A, Lleonart J. Otolith size changes related with body growth, habitat depth and temperature. Environ Biol Fishes. 1993;37:297-306.

Ma BS, Xie CX, Huo B, Yang XF, Huang HP. Age and growth of a long-lived fish Schizothorax o'connori in the Yarlung Tsangpo River, Tibet. Zool Stud. 2010; 49:749-59.

Matic-Skoko S, Ferri J, Skeljo F, Bartulovic V, Glavic K, Glamuzinac B. Age, growth and validation of otolith morphometrics as predictors of age in the forkbeard, Phycis phycis (Gadidae). Fish Res. 2011;112:52-8.

McFarlane G, Schweigert J, Hodes V, Detering J. Preliminary study on the use of polished otoliths in the age determination of Pacific sardine (Sardinops sagax) in British Columbia waters. Calif Cooperative Oceanic Fisheries Invest Rep. 2010;51:162-8.

Megalofoou P. Comparison of otolith growth and morphology with somatic growth and age in young-of-the-year bluefin tuna. J Fish Biol. 2006;68:1867-78.

Mehanna SF, Salem M. Population dynamics of rond sardine Sardinella aurita lin EL-ARISH waters, Southeastern Mediterranean, Egypt. Indian J Fundam Appl Life Sci. 2011;1(4):286-94. ISSN: 2231-6345 (Online) http://www.cibtech.org/jls.htm in Vol. 1 (4). http://www.cibtech.org/J-LIFESCIENCES/PUBLICATIONS/2011/ Vol\%201\%20No.\%204/JLS\%2001-04-Contents.htm.

Mendoza RPR. Otoliths and their applications in fishery science. Ribarstvo. 2006; 64:89-102.

Metin G, Ilkyaz AT. Use of otolith length and weight in age Determination of Poor Cod (Trisopterus minutus Linn. 1758). Turk J Zool. 2006;32:293-7.

Nair RV. The growth rings on the otoliths of the Oil sardine, Sardinella longiceps CUV and VAL. Curr Sci. 1949;18:9-11.

Pombo L, Elliott M, Rebelo JE. Ecology, age and growth of Atherina boyeri and Atherina presbyter in the Ria de Aveiro, Portugal. Cybium. 2005:29:47-55.

Popper AN, Ramcharitar J, Campana SE. Why otolith? Insights from inner ear physiology and fisheries biology. Mar Freshw Res. 2005;56:497-507.

Rizkalla SI, Bakhoum SA. Some biological aspects of Atlantic stargazer Uranoscopus scaber Linnaeus, 1758 (Family: Uranoscopidae) in The Egyptian Mediterranean Water. Turk J Fisheries Aquat Sci. 2009;9:59-66.

Salarpouri A, Darvishi M, Safaei M, Akbar Zadeh G, AliSeraji F, Behzadi S, Momeni M, Rameshi H, Seyd Moradi Sh, Mohebbi P, Parvaresh M, Valinassab T and Dehqani R. Biological survey on small pelagic fishes (sardine \& anchovy) stocks in coastal waters of Hormozgan province (Qeshm Island \& Bandar Lengeh) with emphasis on Sea surface temperature, Plankton. Fisheries Res Inst Iran, Tehran (Iran). 2009. p. 116. http://agris.fao.org/agris-search/search. do?recordID=IR201 1000026. http://en.pgoseri.ac.ir/portal.aspx?tabid=361

Sen D, Aydin R, Calta M. Relationships between fish length and otolith length in the population of Capoeta Capoeta Umbla (Heckel, 1843) inhabiting hazar Lake, Elazic, Turkey. Arch Pol Fisheries. 2001;9:267-72.

Silva A, Carrera P, Masse J, Uriarte A, Santos MB, Oliveira PB, et al. Geographic variability of sardine growth across the northeastern Atlantic and the Mediterranean Sea. Fisheries Res Elsevier. 2008;90:56-69.

Tuset VM, Lombarte A, ASSIS CA. Otolith atlas for the western Mediterranean, north and central eastern Atlantic. Scientia Marina. 2008;27:7-198.

Ward TM, Burch P, Lvey RA. South Australian sardine (Sardinops sagax) fishery: Stock Assessment Rport 2012. Report to PIRSA Fisheries and Aquaculture. South Australian Research and Development Institute (Aquatic Sciences), Adelaid. SARDI publication No. F2007/000765-4. SARDI Res Rep Ser No. 2012;667:101.

Ward TM, Rogers PJ, Stephenson P, Schmarr DW, Strong N, McLeay LJ. Implementation of an Age Structured Stock Assessment Model for Sardine (Sardinops sagax) in South Australia. Report to the Fisheries Research and Development Corporation. South Australian Research and Development Institute (Aquatic Sciences). SARDI Res Rep Ser No. 2005;125:130.

Watanabe Y, Nakamura M. Growth trajectory of the larval Japanese sardine, Sardinops melanostictus, transported into the Pacific coastal waters off central Japan. Fish Bull. 1998;96:900-7.

Yaremko M.L. Age determination in Pacific sardine, Sardinops sagax. NOAA Tech Memo NMFS. 1996. p. 596. https://www.amazon.com/determination-Pacificsardine-Sardinops-Yaremko/dp/1125502940/177-2111744-8484145?ie= UTF8 $^{*}$ Version $*=1 \&^{*}$ entries $*=0$

Zorica B, Sinovcic G, Vanja Cikes Kec V. Preliminary data on the study of otolith morphology of five pelagic fish species from the Adriatic Sea (Croatia). ACTA ADRIAT. 2010:51:89-96. 